\title{
Proteomics en de moleculaire effecten van voeding; geen eitje, maar een piece of cake
}

Citation for published version (APA):

Mariman, E. C. M. (2003). Proteomics en de moleculaire effecten van voeding; geen eitje, maar een piece of cake. Universiteit Maastricht. https://doi.org/10.26481/spe.20030523em

Document status and date:

Published: 23/05/2003

DOI:

$10.26481 /$ spe.20030523em

Document Version:

Publisher's PDF, also known as Version of record

\section{Please check the document version of this publication:}

- A submitted manuscript is the version of the article upon submission and before peer-review. There can be important differences between the submitted version and the official published version of record. People interested in the research are advised to contact the author for the final version of the publication, or visit the DOI to the publisher's website.

- The final author version and the galley proof are versions of the publication after peer review.

- The final published version features the final layout of the paper including the volume, issue and page numbers.

Link to publication

\footnotetext{
General rights rights.

- You may freely distribute the URL identifying the publication in the public portal. please follow below link for the End User Agreement:

www.umlib.nl/taverne-license

Take down policy

If you believe that this document breaches copyright please contact us at:

repository@maastrichtuniversity.nl

providing details and we will investigate your claim.
}

Copyright and moral rights for the publications made accessible in the public portal are retained by the authors and/or other copyright owners and it is a condition of accessing publications that users recognise and abide by the legal requirements associated with these

- Users may download and print one copy of any publication from the public portal for the purpose of private study or research.

- You may not further distribute the material or use it for any profit-making activity or commercial gain

If the publication is distributed under the terms of Article $25 \mathrm{fa}$ of the Dutch Copyright Act, indicated by the "Taverne" license above, 


\section{Proteomics en de moleculaire effecten van voeding: geen eitje, maar een piece of cake}




\section{Collofion}

Basisontwerp en vealisatie: Unigraphic, Universiteit Masatricht

15 IN $90-5681-793-2$

NUR 8.82

Alle rechten woorbehouden. Niets uit deze witgave mag worden verveelwaudigd, opgestagen in een geautomatiserd gegevensbestand of openbaar gemaakt, zonder voorafgoande schrifteWijke toestemming van de autevir of uitgever. 


\title{
Proteomics en de moleculaire effecten van voeding: geen eitje, maar een piece of cake
}

\author{
Rede \\ uitgesproken op vrijdag 23 mei 2003 te Maastricht bij \\ de aanvaarding van het ambt van hoogleraar in de \\ Functionele Genetica aan de Universiteit Maastricht \\ door
}

Prof. Dr. Edwin C.M. Mariman

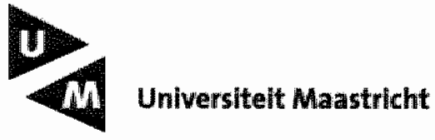


Voor Juanita, Rayna en Marlinda Voor mijn ouders 


\title{
Proteomics en de moleculaire effecten van voeding: geen eitje, maar een piece of cake
}

\author{
Mijneer de Rector Magnificus. \\ Zeer gewaardeerde toehoorders,
}

\section{Het Human Genome project}

Wat homo sapiens het meest van andere organismen op aarde onderscheidt, is het bewuste streven om zijin grenzen te verleggen. Standaard woorbeelden uit de vorige eeuw zijn het terugdringen van vele besmettelijke ziekten en het plaatsen wan de mens op de maan. Als plèce-de-résistance werd begin jaren negentig aangevangen met het ontrafelen van het erfelik materiaal wan de mens, d.w.z. het vaststellen van de basen-volgorde wan het DNA. Men kan dat vergeljken met het ontcijferen wan een boek met 3 miljard tekens op basis van een alfabet bestaande uit vier letters: A, G, C en T. Het opmerkelijke was, dat er voor dit Human Genome Project een tijdspad werd uitgezet waarbij al rekening gehouden was met nog komende technologische ontwikkelingen, die het project door de jaren heen steeds sneller zouden doen verlopen. Geen ijdele inschatting want deze voorspelling is precies zo uitgekomen. Inmiddels beschikken wij over een goed bruikbare versie van het menselijk genoom en in principe zijn daarmee alle genem, de erfelijke factoren van de mens bekend. Op zichzelf een walar meesterwerk. Echter, gaandeweg werden de contouren zichtbaar van het wervolgonderzoek. Het kennen wan de basen-volgorde van aile genen wil nog niet zeggen dat we ook hun functie kennen, laat staan dat wij weten welke genen op welke manier en op welk moment met elkaar en met invloeden wanuit de omgeving interactie aangaan. En laat dat nu juist het niveau van kennis zijn, dat nodig is om tot een beter begrip te kunnen komen van de levensprocessen in de gezonde mens en de storingen die daarin kunnem optreden en aanleiding geven tot zlekte. Het ontrafelen van die complexe moleculaire interacties als grondslag voor gezondheid en zlekte is het terrein van de Functionele Genetica.

Er zijn talloze eigenschappen die bepaald worden door zowel een erfelijke aanleg op basis van vele genen alsmede door omgevingsfacto ren. We spreken daarbij in de genetica ower multifactoriële kenmerken. We hoeven maar te denken aan de frequent voorkomende aandoenin. 
gen zoals hart- en vaatziekten, diabetes, kanker en reuma. Opvallend is dat de incidentles van dergelijke volksziekten in de loop der jaren sterk kunnen fluctueren. Dat blijkt grotendeels toe te schrijven aan verandering in omgevingsinwloeder. Zo is in de decennia na de tweede wereldoorlog de incidentie van neurale buisdefecten, spina bifida en anencephalie, sterk gedaald omdat de woeding in de loop der jaren rijker werd aan bepaalde vitaminen. Een ander voorbeeld is de teruggang in het aantal gevallen wan longkanker onder mannen en de toename bij vrouwen door een veranderd rookgedrag. De invloed van de omgeving is dus van evident belang voor het ontstaan of juist het niet ontstaan van dergelijke multifactoriële aandoeningen. De belangrijke les die hieruit te halen valt is, dat het veranderen, of kunstmatig manipuleren van de orngevingsfactoren een middel bij uitstek is om volksziekten terug te dringen. De voeding lijkt zich in het bijzonder te lenen als medium voor preventie. In het vervolg van mijn betoog zal ik mij daarom tot de voeding als omgevingsfactor beperken.

Enkele voorbeelden zijn hier op hun plaats. Een natrium-arm dieet ter woorkoming van hoge bloeddruk, wet- en suiker-arme producten ter voorkoming van overgewicht, toegevoegde mineralen om botontkalking tegen te gaan, plant stanolen en sterolen in margarine om het serum cholesterol gehalte omlaag te brengen en daarmee de kans op hart- en vaatziekten, enz... Wat opvalt is, dat al deze toepassingen gebaseerd zijn op epidemiologische, metabole of klinische studies. Van het werkingsmechanisme op moleculair niveau weten we nog bijna niets. Welke genen in hun expressie door deze dieet-aanpassingen beïvloed worden en aldus leiden tot een gunstig resultaat, is onbekend. De functionele genetica probeert hierin werandering te brengen door rechtstreeks de genen op te sporen die ten grondslag liggen aan dergelijk voedinggerelateerde aandoeningen. Het is de verwachting dat met de nieuw verkregen kennis van gen-gen en gen-voeding interacties gerichte methoden van preventie zullen kunnen worden opgesteld. Een fase van moleculair gedefinieerde functional foods zal dan aanbreken.

\section{Functionele genetica, kiezen voor RNA of eiwit}

Laten we allereerst eens kijken hoe genen zich in cellen en weefsels laten gelden. Dat verloopt volgens het aloude centrale dogma van de biochemie. Elk gen, dat als DNA in de celkern is opgesloten kan worden overgeschreven in RNA waarbij de coderende informatie vastgelegd door de basen-volgorde, exact wordt overgenomen. Het RNA migreert naar het ribosoom in dle celwloeistof waar de code wordt afgelezen en 
wordt gebruikt om aminozuren aan elkaar te rijgen. De genetische code bepaalt de keuze en volgorde van de aminozuren. De opgevouwen aminozuur-ketting, het eiwit, is in staat om een specifieke functie uit te oefenen. Eiwitten zijn de ware werkpaarden van de cel, de uitwoerders van de levensprocessen. Functies m.b.t. nutriënten kunnen zijn de selectie, transport, vertering, opslag, uitscheiding, enz... Eiwitten zullen daarom grote invloed hebben op de concentraties van nutriënten en metabolieten in ons lichaam. Anderzijds zal het beïnvloeden van onderdelen van het metabolisme door het dieet ertoe leiden dat de betrokken eiwitten hun functioneren daarop aanpassen, bijvoorbeeld doordat die cellen voor de betreffende genen plotseling meer of juist minder RNA en/of eiwit gaan maken. Er is dus sprake van een uitgebalanceerde wisselwerking tussen genexpressie enerzijds en voeding anderzijds.

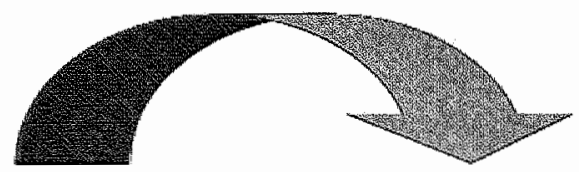

\section{GEN-EXPRESSIE (RNA - EIWIT)}

\section{VOEDING}

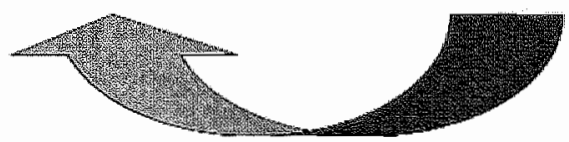

Deze wisselwerking tussen genexpressie en voeding kan worden gebruikt om de genen op te sporen die betrokken zijn bij dieet-afhankelijke aandoeningen zoals obesitas, diabetes en hart-en vaatziekten. In de weefsels en cellen van de diabetes patiënt zal de expressie veranderd zijn van genen, die zorg dragen voor de regulatie van de glucose en vetzuur spiegels. Voor het identificeren van die genen is het noodzakelijk te beschikken over wetenschappelijke methoden, die het mogelijk maken om tegelijkertijd de activiteit van zoveel mogelijk genen, het liefst van alle 35.000, te meten. Als wetenschapper heeft men de keuze om de gen-activiteit te gaan meten op RNA niveau (transcriptomics) of op het niveau van het eiwit (proteomics). De benodigde methoden zijn er thans, ten minste ten dele. Na meer dan tien jaar van ontwikkeling stelt 
de DNA-chip ofwel DNA-microarraly ons thans in staat om wan bijna alle genen de RNA concentratie tegelijkertijd te bepalen. Dit type onderzoek is dan ook momenteel bijzonder populair. Daarentegen staat de eiwittechnologie in feite nog in de kinderschoenen en de huidige wetenschappelijke methoden laten slechts toe de eiwit-expressie van een rellatief klein deel van alle genen te bekijken, in de orde van honderden tot enkele duizenden. Desalmiettemin heb ik in mijn onderzoek gekozen voor een aanpak middels proteornics.

De belangrijkste argumenten om voor een proteomics aanpak te kiezen zijn de volgende. Zoals gezegd zijn de eiwitten de arbeiders van de cel en hebben direct invloed op het verloop van de levensprocessen. Het RNA is slechts de boodschapper die de genetische code van kern naar celvloeistof overbrengt. Verder blijkt steeds vaker dat de RNA concentratie geen afspiegeling is van de concentratie van het bijbehorende eiwit. Kijkt men naar het RNA dan weet men in veel gevallen nog steeds niet wat er met het eiwit aan de hand is. Maar wellicht het sterkste argument om een geneticus te doen kiezen voor eiwit is door Klose et al. beschreven (Nat. Genet. 30:385-392, 2002). Functionele eiwitten kunnen namelijk worden beschouwd als multifactoriële entiteit. Allereerst moeten op basis van de bouwtekening, de genetische code, de juiste amino-

TOTSTANDKOMING VAN EEN FUNCTIONEEL EIWIT

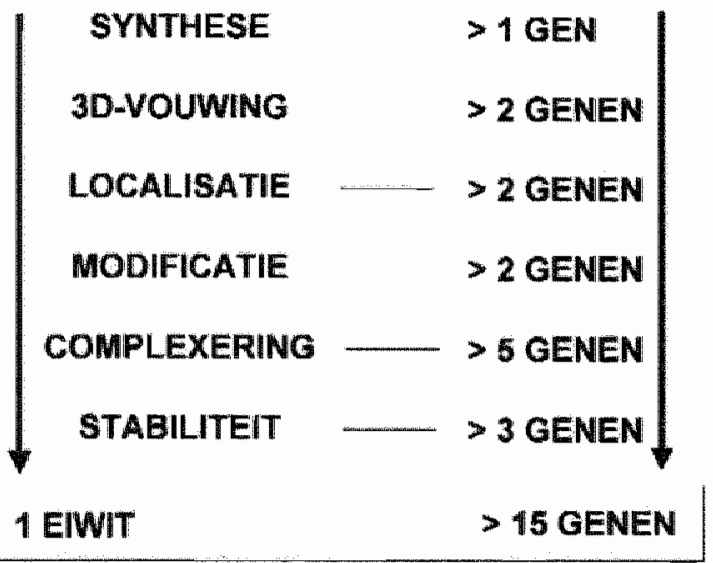


zuren alan elkaar gezet worden. Vervolgens dient deze keten opgevouwen te worden tot de juiste 3-dimensionale structuur. Daarvoor zijn naast co-factoren andere eiwitten (genen) nodig. Eenmaal in de juiste vorm moet het door weer andere eiwitten (genen) getrans porteerd worden naar de juiste plaats in de cel, bijvoorbeeld de kern of het mitochondrion. Ondertussen moet het onder invloed van de daarvoor toegeruste eiwitten (genen) de juiste veranderingen ondergaan zoals fosforylering of glycosylering. Daarna kan het associëren met partnereiwitten (genen) am als onderdeel van een complex te functioneren. Tenslotte moet de concentratie van het eiwit op peil worden gehouden door stabiliserende en afbraak-bevorderende eiwitten (genen). Al die modulerende genen zijn samen nodig om het ene eiwit optimaal te laten functioneren. Slecht functioneren van een enkel eiwit kan ziekte tot gevolg hebben terwijl de reden van het slecht functioneren kan liggen bij tientallen verschillende genen. Het concept van de complexe multifactoriële ziekte kan dus worden verklaard vanuit een enkel eiwit met een afwijkende functie. Zoeken naar een afwijkend eiwit lijkt dus minstens zo elegant en hoopvol als zoeken naar de wele risico-bepalende genen via genoomscans of DNA-microarrays. Mijn keuze is daarom gevallen op proteomics, maar wat is proteomics eigenlijk.

\section{Proteomics}

Een algemene definitie van proteomics is: het in kaart brengen van de functionele aspecten van zoveel mogelijk, zoniet alle eiwitten in organellen, cellen, weefsels en organen om op basis dlaarvan eigenschappen en kenmerken van een organisme te verklaren. Geen eitje, want vanwege alternatieve RNA processing en posttranslationele modificatie kan één gen meerdere eiwitten produceren. Het proteoom wordt in orvang geschat op $200.000-300.000$ verschillendle eiwitten. Sommige wetenschappers beweren echter dat door uitvoering van het Human Proteome Project alle eiwitten met hun functie binnen acht jaar bekend zullen zijn. De onlangs gepubliceerde kaart wan interacties tussen alle eiwitten van gist wordt daarbij gepresenteerd als een proof-ofthe-pudding ( $H 0$ et al., Nature 415:180-183, 2002). Dat dit geen sinecure is $s_{\text {w }}$ zal duidelijk zijn en wederom wordt vertrouwd op een nog komende technologische revolutie. Met de toepassing van massaspectrometrie als methode woor de snelle en bijzonder accurate analyse van eiwitten, lijkt deze revolutie in gang te zijn gezet. 


\section{Proteomics in Maastricht}

Om in Maastricht op academisch niveau de toegankelijkheid voor proteomics te stroomlijnen ben ik in 2001 met ondersteuning vanuit de Brede OnderzoekStrategie (BOS) begonmen met het oprichten van het Maastricht Proteomics Center (www. proteomics unimaas.nl), wat eind vorig jaar is geformaliseerd met het feestelike openingsymposium. Naast cen aantal faciliteiten in apparatuur en methodieken werd een multidisciplinaire kerngroep samengesteld van geinteresseerde en ter zake deskundige wetenschappers uit diverse vakgroepen van de faculteiten voor Gezondheidswetenschappen en Geneeskunde en het Academisch Ziekenhuis Maastricht met onderzoekslijnen in de research instituten NUTRIM, CARIM en GROW en met een link naar de BloMedische Technologie van de TU/e. Thans beschikken wij over mogelijkheden voor het bestuderen van (groepen van) eiwitten voor wat betreft hun identiteit, concentratie, modificatie, turnover, en chemische eiwit-synthese. Ook landelijk werden onze activiteiten gezien en erkend, getuige een korte opmerking in "Onderzaek Nederland' van 22 november 2002. Toen echter de taart van ICES-KIS investeringsgelden moest worden verdeeld, werd plotseling onze expertise afgedaan met de term 'high-throughput klinische screening' (Onderzoek Nederland, 17 januari 2003). Gelukkig wordt onze deskundigheid inmiddels door vele onderzoeksinstituten en de industrie onderschreven en functioneert het Maastricht Proteomics Center als succesvolle demo-site. Voor de verdere ontwikkeling van proteomics blijken contacten binnen de transnationale Universiteit Limburg zeer stimulerend en potentiële partners kunnen worden gewonden in de driehoek Maastricht-Aken-Luik, maar natuurlijk ook tot ver daarbuiten. Voorts wordt in samenwerking met de industrie gewerkt aan enkele technologieën met gebruik van antilichamen, die diepgaande vervolgstudies aan individuele eiwitten gemakkelijker zullen maken. E.e.a betekent wel dat er in Maastricht ook de komende tijd in proteomics geinvesteerd dient te worden om te komen tot fundamenteel en klinisch toponderzoek. Ik hoop dat BOS 2 hier een mogelijkheid toe zal bieden. Gezien de veelvoud van elkaar snel opvolgende ontwikkelingen in het proteomics veld is het van belang om voortdurend vooruit te kijken, innovatief bezig te zijn, focus te houden en de juiste targets te kiezen.

\section{Proteomics in fundamenteel onderzoek}

Thans wil ik u duidelijk proberen te maken hoe proteomics technieken momenteel door ons in het onderzoek worden aangewend. Ons 
onderzoek kent globaal twee lijnen, onderzoek naar het functioneren van de darm in het kader van een IOP-genomics programma, en onderzoek naar het ontstaan van obesitas. Over dat laatste wil ik het hier hebben. Obesitas, ofwel ernstig overgewicht, is een groelend probleem van de Westerse samenleving en zal in toenemende mate komende jaren een beslag leggen op de budgetten van de gezondheildszorg. Verwacht wordt dat in 2015 een op de vijf volwassen Nederlanders zal lijden aan ernstig overgewicht met grote risico's op diabetes, hart-en vaatziekten en sommige vormen van kanker. Reden te meer om deze aandoening te bestudieren en via een beter begrip te kunnen zoeken naar wegen voor preventie. Het stapelen van vetzuren is een evident onderdeel van obesitas en gaat in het lichaam gepaard met de ontwikkeling, de differentiatie, van voorlopercellen (pre-adipocyten) tot volwassen vetcellen (adipocyten). Dit lichamelijk systeem is ongetwijfeld ontworpen om vroeger

\section{VETCEL DIFFERENTIATIE}

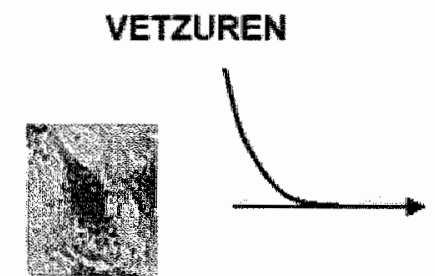

VOORLOPER CEL

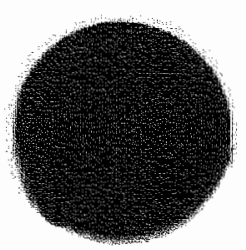

VETCEL

in tijden wan voedselovervloed een reservevoorraad alan te leggen en die in tijden van schaarste te mobiliseren. In onze samenleving met een continu aanbod van voeding en met een verminderde lichaamsbewe. ging is de balans doorgeslagen in de richting van vet-opslag in de wolwassen vetcellen. Wij proberen door middel van eiwit-studies de genen te identificeren die een cruciale rol spelen bij de ontwikkeling wan vetcellen. Tegelijkertijd wordt op moleculair niveau gekeken wat de invloed van voedingsstoffen op dit proces is. Uiteraard wordt ook het omgekeerde proces bestudeerd, warbij de genen worden opgespoord die de 
vetzuur afgifte door vetcellen bewerkstelligen. Om een zo compleet mogelijk beeld te krijgen van de betrokken genen laten wij het proces van de-differentiatie op drie manieren verlopen: via het hongeren van vetcellen, het behandeler van vetcellen met de ontstekingsmediator TNFa, en door het gebruilk van het gemodificeerde vetzuur TA dat in dieren aanleiding geeft tot gewichtswerlies (samenwerking met WURIKLT en de industrie). Ook nu weer worden effecten van specifieke nutriënten op deze processen onderzocht met het oog op toekomstige interventie mogelijkheden.

Met onze experimenten kijken wij naar de concentratie-verandering van zoveel mogelijk eiwitten in de zich ontwikkelende cellen, een vorm van protein-profiling. Eiwitten geisoleerd uit voorloper cellen en volwassen vetcellen worden electroforetisch gescheiden in twee dimensies, volgens lading en volgens molecuulgewicht. De verkregen tweedimensionale elwit-patronen worden software-matig over elkaar gelegd om de kwantitatieve werschillen op te sporen. Ofschoon het. proteoom dat op deze wijze kan worden bestudeerd, in omvang beperkt is, hebben wij inmiddels een aantal eiwitten gevonden waarvan de concentratie verandert in relatie tot het stadium van vetcel-ontwikkeling of in relatie tot

\section{VOORLOPER CELLEN}

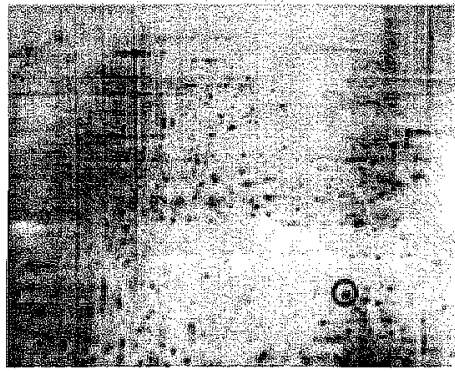

VOLWASSEN CELLEN

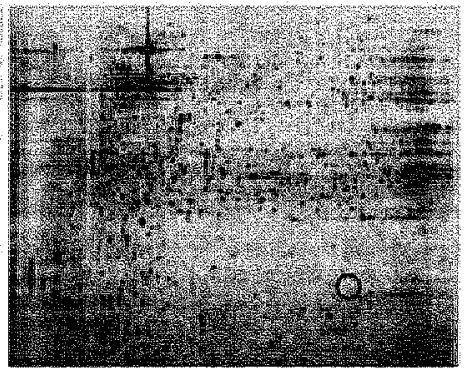

de gegeven behandeling. Dergelijke eiwitten markeren genen waarvan de expressie verandert tijdens de vetcel differentiatie. Om deze genen te identificeren wordt van elk eiwit een peptide fingerprint gemaakt door digestie met specifieke proteasen en bepaling van de molecuulmassa van de discrete fragmenten met behulp van MALDI-TOF MS (matrix assisted laser desorption ionization-time of flight mass spectrometry). 
Deze experimenteel verkregen fingerprint wordt vergeleken met de in silico berekende fingerprints van alle mogelijke eiwitten op basis van gegevens uit het Humane Genoom Project. Zodra een significante matching wordt gevonden, is de identiteit van het betreffende eiwit bekend. Geen matching betekent het uitvoeren van meer geavanceerde massa spectrometrie, tandem-MS, om peptiden te sequencen, dwz de aminozuur volgorde vast te stellen, of te bekijken of er sprake is van posttranslationele modificatie. Het aldus opsporen en identificeren van cruciale eiwitten voor vetcel (de-)differentiatie stelt ons hopelijk in de toekomst in staat de betreffende cellulaire en metabole paden zodanig met een gepast dieet te beïnvloeden, dat vetstapeling wordt onderdrukt en vetafgifte of -verbranding wordt bevorderd.

\section{Nutrigenomics}

Het beschreven onderzoek is een onderdeel van een geheel nieuw onderzoeksgebied: nutrigenomics. Daarbij draait het om studies waarin met genomics methoden effecten van voeding-gen interacties worden onderzocht. Om dit veld in Nederland te stimuleren werd in 2001 het Center for Human Nutrigenomics opgericht (www.nutrigenomics.nl) ondergebracht bij de onderzoeksschool V:AG. Naast het samenbrengen van lopende nutrigenomics projecten, o.a. opgestart vanuit het NWO initiatief voeding en chronische ziekten, en naast het organiseren van talrijke thema dagen en een jaarlijkse masterclass, heeft het centrum een zestal elgen AlOs gelanceerd. Ill ustratief voor het belang van proteomics is, dat bij de helft van deze AlOs proteomics onderdeel is van hun onderzoeksstrategie. Thans richt het centrum zijn blik op Europa met de aanvraag van een Network of Excellence Nutrigenomics waardoor o.m. de efficiëntie, de ontwikkeling en toepassing van proteomics methoden voor het bestuderen van moleculaire effecten van voeding zullen worden verdiept. Inmiddels is een proteomics masterclass en workshop voorzien voor het woorjaar van 2004 op locatie Maastricht. Naast dit alles loopt in Nederland een aanvraag voor een innovatief cluster Nutrigenomics ondergebracht binnen het WCFS, het Wageningen Center for Food Sciences, waar de Universiteit Maastricht middels het onderzoeksinstituut NUTRIM deel van uitmaakt.

\section{Proteomics, a piece of the cake}

Uit voorgaande betoog zou men kunnen opmaken dat ik proteomics. beschouw als de zaligmakende aanpak van het moderne genomics onderzoek aan complexe eigenschappen en ziekten. Dat wil ik hier 
enigszins nuanceren. Tot voor kort werden voeding-gerelateerde aandoeningen bestudeerd door de interactie te bekijken van éen enkele woedingsstof op één enkel gen. De omics-revolutie maakt thans een brede benadering mogelijk waarbij de invloed van een mengsel van voedingsstoffen op vele genen kan worden bekeken. Zoals in de inleiding gezegd kan een dergelijke studie op verschillende niveaus worden aangepakt, namelijk dat van het RNA of het eiwit. Maar uit experimenten

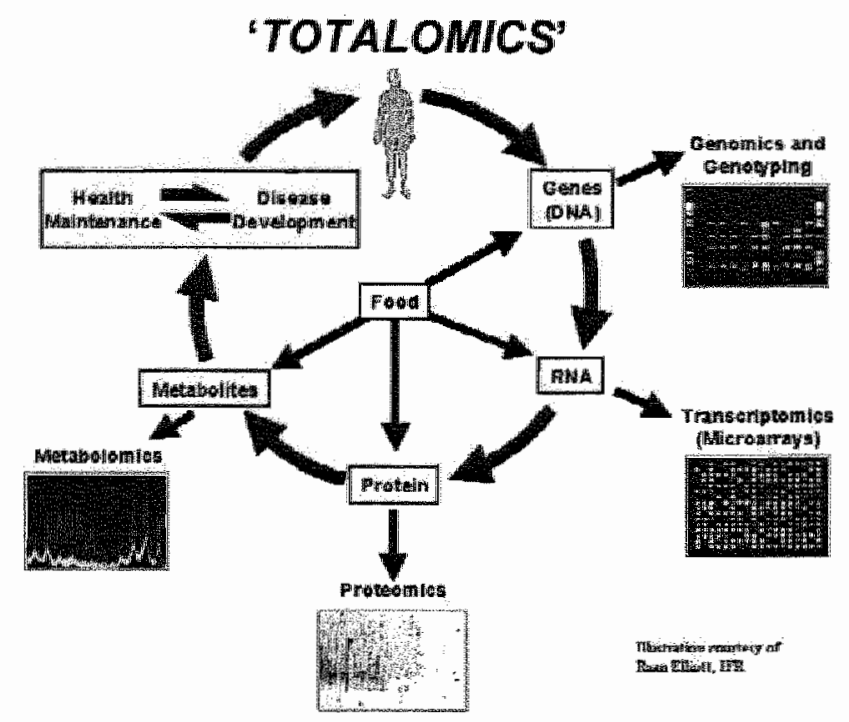

met DNA-microarrays en protein-profiling blijkt steeds vaker dat de regulatie van genexpressie zo veelzijdig is, dat de resultater van beide invalshoeken nodig zijn om een situatie te kunnen begrijpen. Dit geldt witeraard in nog bredere zin. Wie het ontstaan van woeding-gerelateerde aandoeningen wil begrijpen, zal alle methoden wit de kast moeten halen en op alle niveaus gegevens moeten verzamelen: dat van het DNA (genetics), dat van het RNA (transcriptomics), dat wan het eiwit (proteomics), dat van het metaboliet (metabolomics) en dat van het organisme (phenomics". Ik zou dat willen betitelen als de "totalomics" benadering. Proteomics is slechts een van die niveaus, het is slechts een piece of the cake, een stuk van de taart die "genomics" kan worden genoemd. Om het onderzoek in Maastricht in de toekomst wat meer een totalomies karakter te geven, wil ik hierbij mijn collegae BOS-hoogleraren oproe- 
pen om met elkaar rond de tafel te gaan zitten en tot een integratie van onze specifieke expertisen te komen.

\section{Aandlachtspunten voor toekomstig onderzoek}

Een paar punten van aandacht zijn hier op hun plaats. Het moderne genomics onderzoek vraagt om een modus voor het omgaan met en het trekken van conclusies uit de grote hoeveelheden gegevens, op het eerste gezicht een mer à boire. Bioinformatica lijkt hiervoor de aangewezen tak van sport en verdere investeringen in deze wetenschap zijn noodzakelijk, ook in Maastricht. Zonder bioinformatica zal elk centrum voor moleculaire genetica of celbiologie in de toekomst vastlopen. Thans staan de ontwikkelingen nog in de kinderschoenen. Dat blijkt bijvoorbeeld uit de analyse van de resultaten van DNA-microarrays. Op allerlei manieren worden de resultaten geclusterd en gegroepeerd of wordt aansluiting gezocht bij reeds beschreven moleculaire paden, maar nieuwe paden zijn er slechts zelden uit te halen. Daarvoor zijn de komende tijd meer doelgerichte functionele studies nodig. Proteomics kan daar een belangrijke steen aan bijdragen, bijvoorbeeld door het zichtbaar maken van gen-gen interacties via het identificeren van transcriptiefactoren (Nordhoff et al., Nat. Biotechnol. 17:884-888, 1999). Uiteindelijk dient de bioinformatica in staat te zijn om de talrijke gegevens te laten versmelten tot in silico modellen van cellen en organismen. Inmiddels is de hierbij behorende term 'systems blology' al regelmatig te horen.

Een tweede aandachtspunt, dat met voorgaande samenhangt, betreft het feit dat huidige omics-wetenschappen 'beschrijvend' zijn. We doen een experiment, zien vele veranderingen en beschrijven deze. Maar zoals een bekende van mij, prof. dr. Harry Ottenheijm, eerder heeft gezegd: "net als in de chemie moet men in de biologie de stap zien te maken van het beschrijven naar het begrijpen". Bellangrijk hierbij is het opstellen van wetenschappelijke hypothesen, die na toetsing aan de beschrijvende resultaten zullen kunnen leiden naar algemene concepten van voeding gen interactie en thun rol bij de levensprocessen. Het two-hit madel van mijn Wageningse collega prof. dr. Michael Müller, is een eerste aanzet daartoe (Müller en Kersten, Nature Reviews 4:7-14, 2003). Daarbij wordt aangenomen dat metabole stress vanwege de voeding en stress voortkomend uit condities zoals ontsteking, beiden inwerken op cellen langs dezelfde receptoren en moleculaire paden en derhalve leiden tot over-stress in weefsels met chronische aandoenin w gen tot gevolg. Een prima model, maar in mijn eigen visie ga lk ook uit van een langdurige verstoring van de natuurlijke interacties tussen 
weefsels. Wat nog goed is voor het ene weefsel, zal reeds leiden tot stress in het andere.

Laat ik een verduidelijking geven aan de hand van het vetweefsel. vetweefsel heeft nast de tijdelijke opslag van energie uit voeding nog. een andere belangrijke functie als endocrien/paracrien orgaan. Vooroper cellen en volwassen vetcellen scheiden talijike stoffen af die samengevat worden met de term adipokines, veelal kleinere eiwitten en peptiden. Een deel van de adipokines heeft als taak het overbrengen van boodschappen tussen het vetweefsel en andere weefsels. Bekend is het leptine, waarvan in knaagdieren is vastgesteld dat het op neuronen in de hersenen kan inwerken, en het hongergevoel onderdrukt. Een logisch
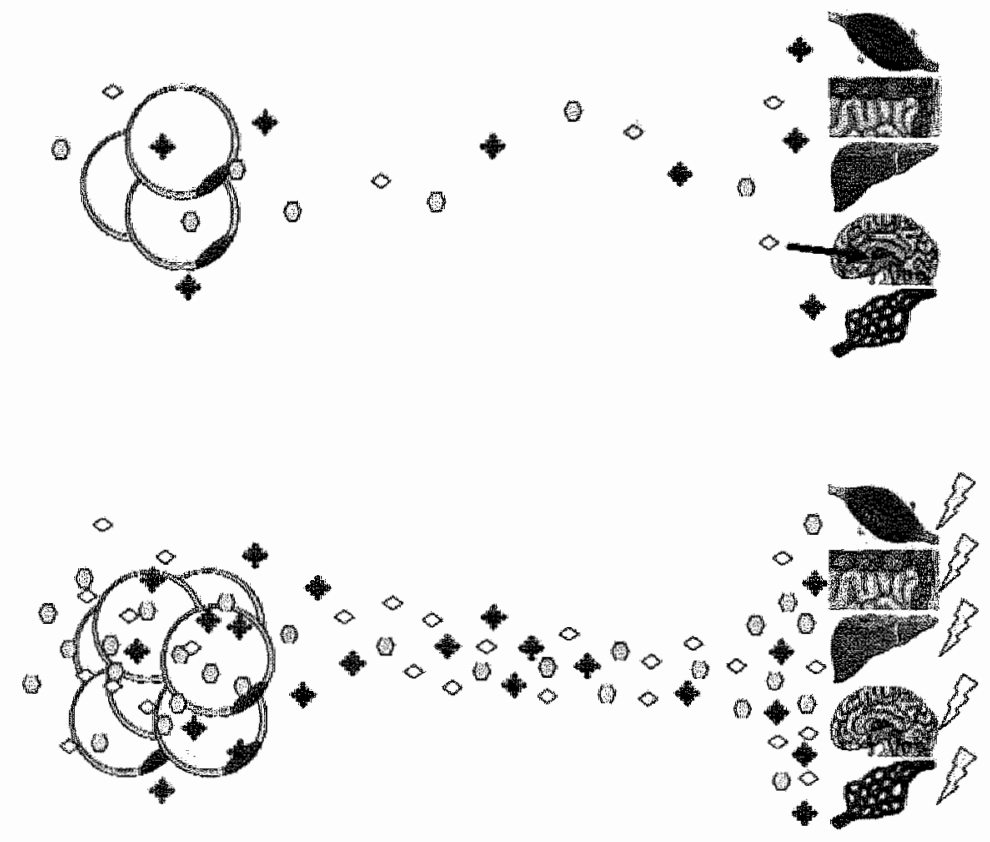

systeem, want als er voldoende vet als reservevoedsel is opgeslagen dient een verdere inname te worden afgeremd. Aangezien de opslag van vet gepaard gaat met de differentiatie van vooriopercellen tot vetcellen, zal bij over-voeding het aantal vetcellen toenemen en daarmee de concentratie leptine, totdat die voldoende hoog is om de neuronen te trig- 
geren. Het dier gaat daardoor automatisch minder eten. Stel dat het toch zou blijven eten, dan zall het aantal wolwassen vetcellen nog verder toenemen. Daarmee zal de leptine concentratie en de concentratie van de overige adipokines stijgen tot een niveau dat pathogeen is voor allerlei weefsels. Al langere tijd wordt gedacht dat adipokines een rol zouden kunnen spelen in het ontstaan van diabetes en hart- en vaatziekten met resistine als boodschapper tussen vet en spier, angiotensine als modu. lator van de bloeddruk, VEGF als conditioner wan de vaatwand en de ontstekingsmediatoren $11 \mathrm{t}, 16 \mathrm{en}$ TNFa. Het zou eenvoudig verklaren waarom obesitas geldt als risico-conditie woor de genoemde volksziekten.

Ons eigen onderzoek (in samenwerking met WU-RIKULT) maakt gebruik van proteomics en transcriptomics methodlen om adipokine productie onder invloed van voedingsstoffen in verschillende stadia van vetcel-differentiatle te bestuderen. Daarnaist wordt gewerkt aan een antibody-array waarmee het niveau van vele adipokines in serum van patiënten gelijktijdig kan worden bepaald. Met het meten wan deze adipokine patronen hopen wij in de toekomst een bewijs te leveren voor het zojuist omschreven model.

Het voorkomen van eiwitten en peptiden als boodschappers tussen weefsels beperkt zich uiteraard niet tot het vetweefsel en het verder doorgronden van het belang van dergelijke moleculen voor de gezondheid van de mens vereist specialisatie, bijwoorbeeld wia het instellen van een bijzondere leerstoel "inter-organ signaling".

\section{Clinical proteomics: toegepast onderzoek en diagnostiek}

Het ontwikkelen van een adipokine antibody array laat zien dat proteomics naast het fundamentele onderzoek, ingezet kan worden voor het beantwoorden van vragen met een meer directe klinische relevantie. Een ander voorbeeld daarvan is ons onderzoek naar de werking van $T Z D$, een geneesmiddel tegen diabetes met de ongewenste bijwerking van gewichtstoename. Onlangs zijn wij begonnen met het bestuderen van de veranderingen die deze stof teweeg brengt in het proteoom vän gekweekte (voorloper) vetcellen. Daarbij zien we een sterke op-regulatie van bepaalde eiwitten, hetgeen duidt op een verandering van specifieke onderdelen van het metabolisme. Wegens geheimhoudingsplicht op basis wan een overeenkomst met de industrie, in toenemende mate karakteristiek voor het hedendaagse onderzoek, kan ik u de details hiervan echter nog niet meedelen. Maar wat het illustreert is, dat we proteomics op academische schaal kunnen aanwenden om dergelijke medicinale (bij)werkingen in meer detail te doorgronden. Die kennis kan 
mogelijk gebruikt worden woor het werbeteren van de geneesmiddelen en hun toepassingen.

Proteornics is momenteel nog geen onderdeel van de diagnostische routine, maar gezien het feit dat eiwitten als arbeiders in de cel aan de wieg staan van de pathologische processen, valt dit spoedig te werwachten. De eerste resultaten met name op het terrein van de oncologie, maar ook op dat van de hart- en vaatzlekten, zijn inmiddels in de literatuur verschenen (Wulfkuhle et al, Nat. Rev. Cancer 3:267-275, 2003: Marshall et al. J. Proteome Res. EST:1r.6, A-L, 2003). In een van die studies werden in het serum van patiënten met ovarium carcinoom met SELDITOF MS (surface enhanced laser disorption ionization time-of-flight mass spectrometry) ziekte-specifieke eiwitten aangetoond, die uiteraard niet bij gezonde personen aanwezig waren (Petricoin et al. Lancet 359:572-577,2002). De diagnose ovariumcarcinoom, kon met een zekerheid van $>95 \%$ op basis van serum eiwitten worden gesteld. Deze bevinding heeft in het patiëntenzorg onderzoek een ware schokgolf teweeg gebracht, die ook in Maastricht is komen aanrollen. En met de inmiddels verenigde kennis en expertise van het Maastricht Proteomics Center wordt die golf thans op de juiste wijze gekanaliseerd door het Kllinische Chernisch Laboratorium onder leiding van mevrouw prof. dr. Marja van Diejen. Een samenwerking die onder MUCH, het Maastrichtse University Center for Health, moet culmineren in een optimale wisselwerking tussen fundamenteel en klinische toegepast moleculair onderzoek. 


\section{Samenvatting}

\section{Dames en heren,}

In de afgelopen 35 minuten heb ik geprobeerd om $u$ bij de hand te nemen en u te leiden door het veelbelovende gebied van de proteomics als onderdeel van de functionele genetica met speciale aandacht voor het voedingsonderzoek. Daarbij heb ik onder meer de volgende stellingen naar voren willen brengen:

1 Met de functionele genetica is een nieuw tijdperk ingeluid van het bestuderen van multifactoriele eigenschappen en aandoeningen in termen van multiple gen-gen en gen-omgeving interacties.

2 Eiwitten zijn vanwege de multifactoriële basis van hun functioneren in deze een ideaal onderzoekstarget.

3 Proteomics is een veelbelovend, zich snel ontwikkelend wetenschappelijk expertise-terrein, dat echter juist vanwege de veelheid van functionele aspecten van eiwilten niet eenvoudig is, geen eitje dus.

4 Proteomics kan met succes worden aangewend binnen het fundamenteel, het pre-klinisch en het toegepast klinisch onderzoek.

5 Het werkelijk begrijpen van de levensprocessen vereist in de toe komst onderzoek op alle omicsmiveaus, een totalomics benadering. en proteomics-resulaten wormen een deel van dat geheel, een 'piece of the cake" of beter nog een 'pars "pro-toto'.

6 De bioinformatica vormt de lijm die de gegevens laat wersmelten en het trekken van conclusies mogelijk moet maken.

7 Wetenschappelijke hypothesen en modellen zljn nodig om van een beschrijvend naar een begrijpend niveau te komen warin wetenschappelijke concepten en wetmatigheden belangrijker zijn dan data alleen.

8 Al deze ontwikkelingen voltrekken zich wat voeding betreft binnem thet onderzoeksveld nutrigenomics.

9 Deze ontwikkelingen zullen leiden tot moleculair gedefinieerde func. tional foods voor de preventie van complexe aandoeningen.

10 Proteomics als onderdeel van de functionele genetica zal in de toe. komst een extra dimensie toevoegen aan het diagnostisch repeitolre van de moderne ziekenhuizen en verzorgingscentra. 
De revolutie die zich op moleculair wetenschappelijk terrein voltrekt, moet zijn weeslag hebben in het onderwijs. Topzorg kan enkel een feit worden indien de zorguerlener een basis aan fundamentele kennis bij zich draagt, welke een integratie is enerzijds van kennis omitrent de moleculaire levensprocessen die in directe relatie staan met ziekte en gezondheld, en anderzijds van kennis omtrent het wel en wee van de patiënt en het zorgstelsel. De chemicus, bioloog, levenswetenschapper, arts en zorg-specialist van de toekomst moet daarom opgelleid worden wolgens de meest moderne inzichten van de wetenschap. lk zie het als mijn taak en uitdaging om daaraan bij te dragen. 


\section{Dankwoord}

Allereerst wil ik mijn dank uitspreken aan het College van Bestuur, het bestuur van de Faculteit Gezondheidswetenschappen, en de directeuren van NUTRIM, CARIM En GROW voor het in mij gestelde vertrouwen. Met name professor Wim Saris moet ik danken voor zijn ondersteuning en niet aflatende vertrouwen in het belang van proteomics voor het moderne toponderzoek op het gebied van de nutrigenomics, en voor het onderzoek in het algemeen aan chronische ziekten in Maastricht. Beste Wim, soms meende ik toch wat twijfel te bemerken met name op momenten dat je met je broer Chris had gesproken maar daar zal ik mij wel in vergist hebben. Dank ook aan professor Klaas Westerterp, die mij in zijn vakgroep geschoven kreeg, en aan alle leden van de vakgroep die milj als wreemde eend snel in hun midden accepteerden.

"Fungen" is de naam van het groepje mensen dat met mij de weg bewaindelt in de wereld wan het genomics onderzoek. Freek, Johan, Egbert, Arjen, Kaatje, Ping Antoine, Andrea, en Dennis, onze eerste stagere, alles staat of valt met jullie enthousiasme en jullie wetenschappelijke bevlogenheid. Die zijn prima in orde, waarvoor dank. Helaas duiken er af en toe zaken op die het enthousiasme op een of andere wijze proberen te temperen zoals het hanteren van de flexwet en de invoeren van U.F.O., het universitaire functieordening systeem. Ik hoop van harte dat dergelijke organisatorische beslommeringen komende tijd wat minder zullen zijn zodat wij ons vol overgave kunnen storten op datgene waar wij voor zijn, wetenschap en onderwijs.

Dank ook aan de leden van de kerngroep van het Maastricht Proteomics Center, voor hun bereidheid om vanaf het eerste uur ongeacht discipline, instituut, faculteit of zliekenhuis, mee te denken aan het grotere geheel. Het bewijst maar eens te meer: in concordia res parvae crescunt!

Als hoogleraar Functionele Genetica in Mastricht vindt je jezelf geplaatst in een netwerk van organisaties en suborganisaties. Om daar te komen waar ik nu sta, hebben vele personen mij in het verleden geholpen. Vanaf mijn allereerste college Biochemie aan de Katholieke Universiteit van Nijmegen door professor Peter Bloemers was ik aan de 
moleculaire levensprocessen verknocht. Mijn promotie-onderzoek op het terrein van de Celbiologie bij professor Walther van Venrooij blijkt thans weer van pas te komen. Want veel van de moderne onderzoeksmethoden blikken toch ergens oude wijn in nieuwe zakken. Mijn leermeester in de Moleculaire Biologie, professor Bé Wieringa, ben ik zeer erkentelijk. Beste Bé, geen moment moest ik mij bedenken toen jij mij een postdoc positie aanbood op de afdeling Anthropogenetica. Daar maakte ik kennis met de Humane Genetica en Moleculaire Genetica. Mijn standvastigheid en doelgerichtheid in het onderzoek, voor zover ik die meen te bezitten, heb ik zeker geleerd van het toenmalige hoofd van die afdeling, professor Hans Hilger Ropers. Beste Hilger, een aansporende uitspraak die mij altijd bijgebleven is is de volgende: "Als je voor je veertigste geen hoogleraar bent, dan wordt je het nooit". Jij stelde mij in staat mijn talenten te ontplooien op het terrein van het genetisch onderzoek aan complexe ziekten samen met Dr. Ben Hamel, hoofd van het Klinisch Genetisch Centrum Nijmegen. Vervolgens kreeg ik de kans om mijn leidinggevende eigenschappen te toetsen als hoofd van de sectie DNA Diagnostiek, een bewogen tijd waarop ik met voldoening terug kijk. Al die mensen, fijne collegae waar ik zovele jaren mee door het onderzoek en de patiëntenzorg ben gegaan, teveel om op te noemen, jullie allen wil ik hier bedanken. Professor Han Brunner, opvolger wan prof. Ropers, beste Han, jij attendeerde mij op de advertentie in Maastricht. Ik hoor je nog zeggen dat je mij absoluut niet weg wilde hebben, maar dat je mij die kans niet wilde ontnemen. Professor Ad Geurts van Kessel, hoofd Cytogenetica in Nijmegen, beste Ad, met jouw levensvisie droeg je bij in mijn beslissing om voor de positie in Maastricht te gaan: "Voor ledereen komt er af en toe in het leven een trein langs en dan heb je de keuze om er op te springen, of niet, maar weet wel dat je straks bij Petrus voor de Poort staat en dat hij aan je vraagt wat je met je leven hebt gedaan. Dan zul je verantwoording moeten afleggen". Hoe kon ik na zo'n uitspraak nog twijfelen.

Beste ouders, ik weet dat het vandaag voor jullie minstens zo bijzonder is als voor mij. Pa, na mijn promotie vroeg je mij hoe lang ik nog moest studeren om professor te worden, waarop ik antwoordde dat je niet voor professor kunt leren, maar dat je als zodanig benoemd moet worden. Het is er thans van gekomen.

Lieve Rayna en Marlinda, van ons wordt wel gezegd, dat wij geen doorsmee geżin zijn. Ik begin dat zowaar te geloven. Sterker nog, ik weet 
het wel zeker. Voor jullie kan het leven niet dymamisch genoeg zijn. Steeds wordt gezocht naar nieuwe prikkels en uitdagingen ${ }_{\text {zoals de }}$ homo sapiens uit het begin van mijn betoog. Ofschoon we net verhuisd waren wan Nijmegen naar Malden, aarzelden jullie geen moment en vroegen meteen wanneer we naar het zuiden zouden afreizen. Dat beangstigt mij wel eens. Soms denk ik dat jullie meer dynamiek van het leven verwachten dan het leven in petto heeft. En dat kan zijn tol eisen. Grijp het leven, en om in de woorden wan Metallica te spreken "nothing else matters!", maar gun jezelf ook af en toe wat rust en reflexie. Jullie mam en ik zullen er in elk geval voor jullie zijn.

Liefste Juanita, liefste Nene, werzamelen is onze gezamenlijke hobby. Maar naast het grote aantal woorwerpen dat het heeft opgeleverd, hebben wij de afgelopen decennia samen met name levenservaringen verzameld, en wel zovele dat die werkelijk met geen pen te beschrijven zijn. Bij elke stap in het leven sta jij naast mij, of het nu om kleine dingen gaat of om ingrijpende zaken. Dus toen Maastricht in de picture kwam, zei je meteen: "als je denkt dat je het kunt, dan moet je het doen". En voor de tweede keer liet jij alles en iedereen achter om met mij op weg te gaan. Geborren aan verschillende kanten van de aardbol lijkt onze harmonie
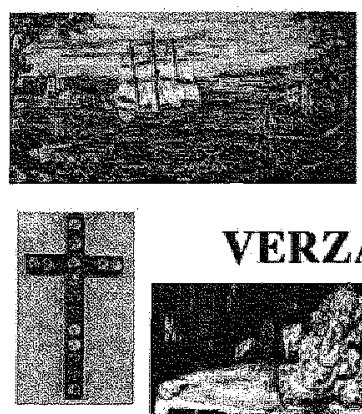

VERZAMELEN
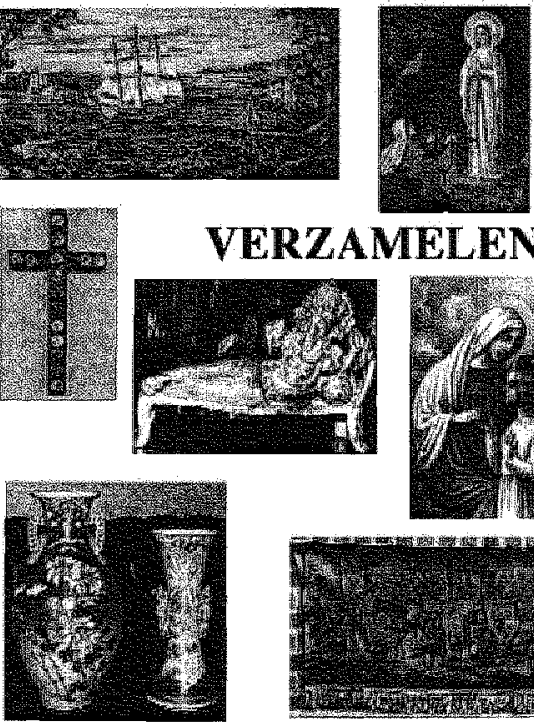
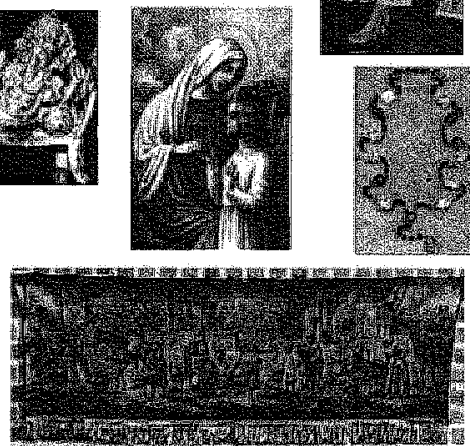

Bezichtiging alleen na afspraak 
grenzeloos. Hoe is dat in godsnaam mogelijk. Dat kan alleen maar als het waar is wat er wordt gezegd, namelijk dat een huwelijk in de hemell gesloten wordt.

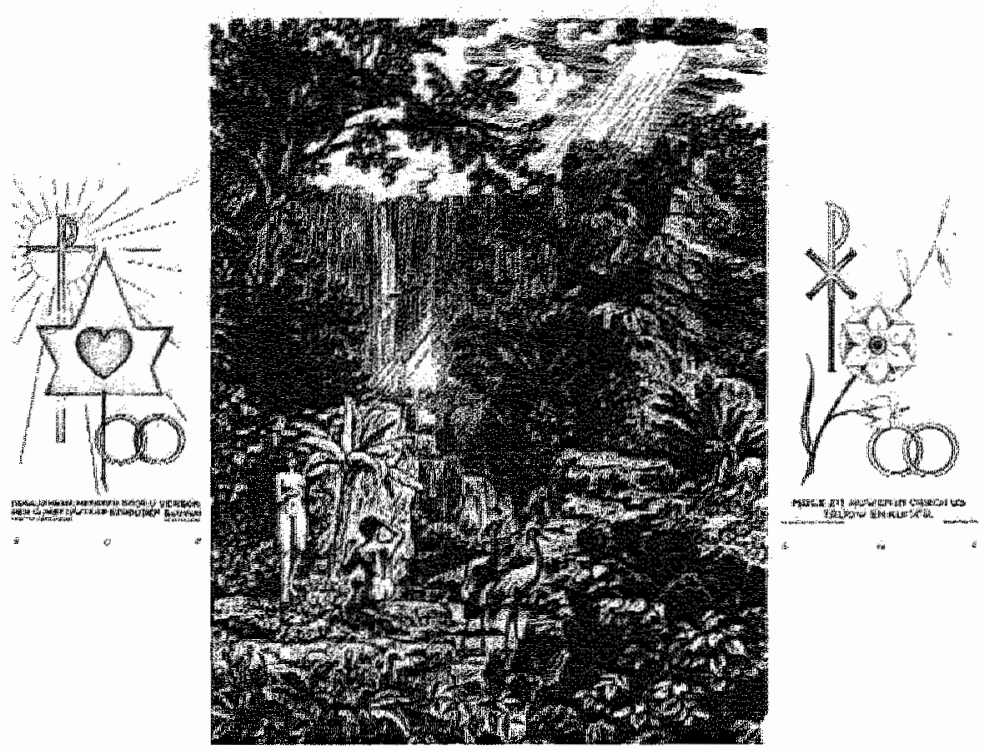

Tenslotte will ik $u$ allen danken voor de belangsteling die u hebt getoond en het feit dat u hier aanwezig hebt willen zijn.

Ik heb gezegd! 